\title{
Optimisation of coagulation process with SIWW is coagulant for colour and COD removal of acid dye effluent using central composite design experiment
}

\author{
Abdelkader Anouzla*, Younes Abrouki, Salah Souabi, Mohammed Safi, Hayat Loukili, \\ Hicham Rhbal, Rachid Slimani \\ Laboratoire de Génie de l'Eau et de l'Environnement, Université Hassan II, Faculté des Sciences et Techniques de Mohammedia, \\ Mohammedia, Maroc \\ Email address: \\ aanouzla@gmail.com (A. Anouzla)

\section{To cite this article:} \\ Abdelkader Anouzla, Younes Abrouki, Salah Souabi, Mohammed Safi, Hayat Loukili, Hicham Rhbal, Rachid Slimani. Optimisation of \\ Coagulation Process with SIWW is Coagulant for Colour and COD Removal of Acid Dye Effluent Using Central Composite Design \\ Experiment. International Journal of Environmental Monitoring and Analysis. Special Issue: Environmental Science and Treatment \\ Technology. Vol. 2, No. 6-1, 2014, pp. 1-5. doi: 10.11648/j.ijema.s.2014020601.11
}

\begin{abstract}
Central composite rotatable design experiment is used to study the effect of coagulation process for acid dye effluents and to optimise the variables such as dye concentration, coagulant dosage and initial $\mathrm{pH}$, which influence the efficiency of colour and COD removal of dye effluents. The steel industrial wastewater ( $\mathrm{SIWW}$ ) $\mathrm{FeCl}_{3}$ rich is used for this study as an original coagulant to remove the acid red 14 dye solutions. A model has been obtained among decolourization, COD reduction and relevant parameters by means of variance analysis and obtained model was optimized. The efficiencies of decolourization and COD reduction for acid dye solution were accomplished at optimum conditions as $98 \%$ and $94 \%$, respectively.
\end{abstract}

Keywords: Optimization, Coagulation, SIWW, Dye Removal, Acid Red 14, Statistical Design Method

\section{Introduction}

Dyes are the one of the major constituents of the wastewater produced from many industries related to textile, paint and varnishes, ink, plastics, pulp and paper, cosmetics, tannery etc., and also to the industries, which produces dyes [1].

Colour is one of the most important hazards in industrial effluents, which needs to be treated [2-7], because the presence of dyes in water reduces light penetration, precluding the photosynthesis of aqueous flora [8]. Besides that, some dyes may cause allergy, dermatitis, skin irritation, and cancer to humans [9] in addition to being mutagenic [10].

Treatment of the textile dye containing effluent is difficult and ineffective with conventional biological processes [11] because many synthetic dyes are very stable to light, temperature and resistant to microbial attack.

Considerable efforts have been made by many researchers to find appropriate treatment systems in order to remove pollutants and impurities of wastewaters emanated from different industries, in particular, textile industry [12-16]. Many chemical and physical methods of dye-removal have been used, including photocatalytic degradation [17], membrane processes [18], adsorption techniques [19], chemical oxidation [20] and coagulation-flocculation [21].

Coagulation-flocculation followed by sedimentation and filtration is used worldwide in the wastewater treatment process before discharge of the treated water to the river. Many coagulants are widely used in the conventional wastewater treatment processes [22]. These coagulants can be inorganic coagulants (e.g., aluminium sulphate, ferric chloride and polyaluminium chloride), synthetic organic polymers (e.g., polyacrylamide derivatives) or naturally occurring flocculants (e.g., microbial flocculants). These coagulants and flocculants are used for different purposes depending on their chemical characteristics [23].

The aim of the present work is to test the ability of the steel industrial wastewater (SIWW) as an original coagulant to remove the acid dye solution. The experiments were planned by using statistical design method [24]. The dye concentration, coagulant dosage and initial $\mathrm{pH}$ are chosen as process parameters. The regression models obtained were used in a constrained optimization to find optimum process conditions for maximum decolourization and COD reduction efficiency 
of the acid red 14 effluents.

\section{Materials and Methods}

\subsection{Materials}

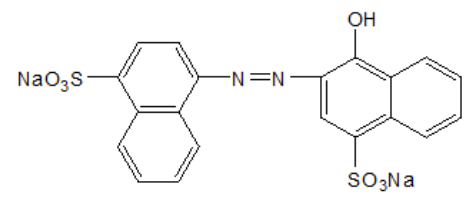

Figure 1. Molecular structure of acid red 14

The acid red 14 was purchased from Aldrich $C_{0}$ with a molecular structure as given in Fig. 1. The characteristics of acid dye are summarized in Table 1.

Table 1. The characteristics of acid red 14

\begin{tabular}{ll}
\hline Parameter & Value \\
\hline Colour index number & 14720 \\
Chromophore & Monoazo \\
Chromotrope & $\mathrm{FB}$ \\
Molecular Weight $(\mathrm{g} / \mathrm{mol})$ & 501.99 \\
$\lambda_{\max }(\mathrm{nm})$ & 515 \\
Chemical Formula & $\mathrm{C}_{20} \mathrm{H}_{12} \mathrm{~N}_{2} \mathrm{Na}_{2} \mathrm{O}_{7} \mathrm{~S}_{2}$ \\
\hline
\end{tabular}

The SIWW was taken from Magreb Steel (Morocco society) and was used as a novel coagulant in this study [25]. The characteristics of SIWW are given in Table 2. Analysis of SIWW sampled at end pipe of this plant indicates a high level of $\mathrm{FeCl}_{3}$. Then this rejection was valorised as coagulant in the treatment of textile wastewater .

The decolourization and COD reduction of dye solutions were examined under coagulation processes by jar-test experiment [26].

Table 2. The characteristics of SIWW

\begin{tabular}{ll}
\hline Parameter & Value \\
\hline $\mathrm{FeCl}_{3}(\mathrm{mg} / \mathrm{L})$ & 1787 \\
Conductivity $(\mathrm{ms} / \mathrm{cm})$ & 26200 \\
$\mathrm{pH}$ value & $<1$ \\
\hline
\end{tabular}

\subsection{Analytical Procedure}

The standard stock solution of $1000 \mathrm{mg} / \mathrm{L}$ including acid dye was prepared in distilled water. The standard working solutions were prepared by further dilution of standard stock solutions. The solutions were prepared for calibration curves by further dilution of standard working solutions. The initial $\mathrm{pH}$ of standard working solutions was adjusted by addition of $\mathrm{NaOH}$ or $\mathrm{H}_{2} \mathrm{SO}_{4}$ to a desired value in the range of 2-6. Samples of dye solutions were measured using a UV/Visible spectrophotometer (Model 7800 UV/VIS) at the beginning and at the end of the experiment. COD removal was detected by using standard methods at the beginning and at the end of the experiment [27]. The percentage of decolourization and COD reduction were calculated as follows. Eq. (1):

Decolourization $\% / C O D$ reduction $\%=\left(1-\mathrm{C}_{0} \mathrm{C}_{0}\right) \times 100$ where $\mathrm{C}_{0}$ is initial dye concentration/COD, $\mathrm{C}$ is final dye concentration/COD after treatment by coagulation with SIWW.

\subsection{Statistical Design of Experiments}

The rotatable central composite design $2^{3}$ was applied to study the effect of three design factors, namely initial $\mathrm{pH}$ of acid dye solutions $\left(\mathrm{X}_{1}\right)$, coagulant dosage $\left(\mathrm{X}_{2}\right)$ and dye concentration $\left(\mathrm{X}_{3}\right)$. The coded levels and the natural values of these factors set in the statistical experiment are shown in Table 3. The design consisted of 16 trials as calculated by the following equation (2):

$$
\mathrm{N}=2^{\mathrm{k}}+2 \times \mathrm{k}+\mathrm{n}_{\mathrm{c}}=2^{3}+2 \times 3+2=16
$$

where $\mathrm{N}$ is the total number of runs, $\mathrm{k}$ the number of factors, and $\mathrm{nc}$ is the number of central points. The distance of the axial points from the centre of the rotatable central composite design (star distance, $\alpha$ ) was calculated [28] by the equation (3):

$$
\alpha=2^{\mathrm{k} / 4}=2^{3 / 4}=1.682
$$

The selected optimization parameters or responses are the following: $\mathrm{Y}_{\mathrm{DEC}}$, decolourization efficiency $(\%)$ and $\mathrm{Y}_{\mathrm{COD}}$, COD reduction $(\%)$. The results of the statistical experiment were treated by the software STATGRAPHICS-Plus (Version 4) to determine the various components of analysis of variance (ANOVA).

Table 3. Study field and coded factors

\begin{tabular}{lllllll}
\hline \multirow{2}{*}{ Natural variables $\left(\boldsymbol{x}_{\boldsymbol{j}}\right)$} & \multirow{2}{*}{ Unit } & \multicolumn{6}{c}{ Coded variables $\boldsymbol{X}_{\mathbf{1}}, \boldsymbol{X}_{\mathbf{2}}, \boldsymbol{X}_{\mathbf{3}}{ }^{*}$} \\
\cline { 3 - 7 } & & $-\boldsymbol{\alpha}$ & $\mathbf{1}$ & $\mathbf{- 1}$ & $\mathbf{+} \boldsymbol{0}$ & $\mathbf{0}$ \\
\hline$x_{1}=$ Initial $\mathrm{pH}$ & - & 2.32 & 3 & 4 & 5 & 5.68 \\
$x_{2}=$ Coagulant dosage & $\mathrm{mL}$ & 0.16 & 0.5 & 1 & 1.5 & 1.84 \\
$x_{3}=$ Dye concentration & $\mathrm{mg} / \mathrm{L}$ & 65.91 & 100 & 150 & 200 & 234.09 \\
\hline
\end{tabular}

* The coded values $X_{j}= \pm 1$ are obtained by the equation: $X_{j}=\left(x_{j}-R_{j}\right) / \Delta$

\section{Results and Discussion}

\subsection{Development of Regression Model Equation}

The corresponding quadratic models for the above optimization parameters were first computed, from which the outliers (statistically unacceptable measurements) were found and excluded from the subsequent calculations. The insignificant effects (factors and interactions) having p-values higher than 0.05 were then excluded, and those with $\mathrm{p}$-values lower than 0.05 were further used being statistically different from zero at the $95 \%$ confidence level.

The experimental design matrix and the corresponding experimental parameters and response value were shown in Table 4. STATGRAPHICS-Plus computer software was used to model and optimize the experimental results. At the end of coagulation processes with SIWW, the final empirical models in terms of coded factors after excluding the insignificant terms for decolourization efficiency $\left(\hat{\mathrm{Y}}_{\mathrm{DEC}}\right)$ and COD reduction $\left(\hat{\mathrm{Y}}_{\mathrm{COD}}\right)$ of acid dye solutions are shown in Eq. (4) 
and Eq. (5), respectively.

$$
\begin{aligned}
& \hat{Y}_{\mathrm{DEC}}=95.44+0.98 X_{1}+11.32 X_{2}-6.96 X_{3}-11.86 X_{2}^{2}-3.38 X_{3}^{2} \\
& \hat{Y}_{\mathrm{COD}}=91.35+1.23 X_{1}+12.16 X_{2}-8.16 X_{3}-13.6 X_{2}^{2}-3.17 X_{3}{ }^{2}
\end{aligned}
$$

Table 4. Experimental design and results for dye removal

\begin{tabular}{lllllll}
\hline Order & \multicolumn{3}{l}{ Coded units of variable } & \multicolumn{2}{l}{ Responses* } \\
\hline Logical & actual & $\boldsymbol{X}_{\mathbf{1}}$ & $\boldsymbol{X}_{\mathbf{2}}$ & $\mathbf{X}_{\mathbf{3}}$ & $\boldsymbol{Y}_{\text {DEC exp. }}$ & $\boldsymbol{Y}_{\text {COD exp. }}$ \\
\hline 1 & 10 & 1 & 1 & 1 & 86 & 79 \\
2 & 12 & 1 & 1 & -1 & 98 & 98 \\
3 & 16 & 1 & -1 & 1 & 63 & 58 \\
4 & 6 & 1 & -1 & -1 & 78 & 73 \\
5 & 2 & -1 & 1 & 1 & 86 & 77 \\
6 & 5 & -1 & 1 & -1 & 97 & 95 \\
7 & 9 & -1 & -1 & 1 & 61 & 56 \\
8 & 4 & -1 & -1 & -1 & 76 & 70 \\
9 & 7 & 1.68179 & 0 & 0 & 98 & 94 \\
10 & 15 & -1.68179 & 0 & 0 & 93 & 90 \\
11 & 13 & 0 & 1.68179 & 0 & 81 & 74 \\
12 & 8 & 0 & -1.68179 & 0 & 42 & 30 \\
13 & 1 & 0 & 0 & 1.68179 & 73 & 68 \\
14 & 11 & 0 & 0 & -1.68179 & 98 & 95 \\
15 & 14 & 0 & 0 & 0 & 96 & 91 \\
16 & 3 & 0 & 0 & 0 & 95 & 92 \\
\hline
\end{tabular}

* Decolourization efficiency $\left(\mathrm{Y}_{\mathrm{DEC}}\right)$ and $\mathrm{COD}$ reduction $\left(\mathrm{Y}_{\mathrm{COD}}\right)$ of acid red 14.

Positive sign in front of the terms indicates synergistic effect, whereas negative sign indicates antagonistic effect. The quality of the model developed was evaluated based on the correlation coefficient value. The R value for Eq. (4) and Eq. (5) was 0.9977 and 0.9959 , respectively. Both the $\mathrm{R}$ values obtained were relatively high, indicating that there was a good agreement between the experimental and the predicted values from the models.

The $\mathrm{R}^{2}$ value for Eq. (4) was 0.9954 and 0.9918 for Eq. (5). This indicated that $99.54 \%$ and $99.18 \%$ of the total variation in the decolourization efficiency and COD reduction of acid red 14 effluents, respectively, was attributed to the experimental variables studied. From the statistical results obtained, it was shown that the above models were adequate to predict the decolourization efficiency and COD reduction of acid dye solutions by coagulation processes with SIWW within the range of variables studied.

\subsection{Decolourization Efficiency of Acid Red 14 Effluents}

The adequacy of the models was further justified through analysis of variance. The ANOVA for the model for decolourization efficiency of acid dye solutions by coagulation processes with SIWW is listed in Table 5.

From this ANOVA, the Model F-value of 360.84 implied that the model was significant. Values of Prob. > F less than 0.05 indicated that the model terms were significant. In this case, initial $\mathrm{pH}$ of acid dye solutions $\left(\mathrm{X}_{1}\right)$, coagulant dosage (X2), dye concentration $\left(\mathrm{X}_{3}\right)$ and the interaction terms $\left(\mathrm{X}_{2}{ }^{2}\right.$ and $\mathrm{X}_{3}^{2}$,) were significant model terms whereas the interaction terms $\left(\mathrm{X}_{1}^{2}, \mathrm{X}_{1} \mathrm{X}_{2}, \mathrm{X}_{1} \mathrm{X}_{3}\right.$ and $\left.\mathrm{X}_{2} \mathrm{X}_{3}\right)$ were insignificant to the response.

Table 5. Analysis of variance for decolourization efficiency of acid dye solution

\begin{tabular}{llllll}
\hline $\begin{array}{l}\text { Source of } \\
\text { variation }\end{array}$ & $\begin{array}{l}\text { Sum of } \\
\text { Squares }\end{array}$ & $\begin{array}{l}\text { Degree of } \\
\text { freedom }\end{array}$ & $\begin{array}{l}\text { Mean } \\
\text { square }\end{array}$ & $\boldsymbol{F}_{\text {exp }}$ & $\begin{array}{l}\text { Significance } \\
\text { test }\end{array}$ \\
\hline Regression & 4034,486 & 9 & 448.2763 & 360.84 & $* * *$ \\
$\beta_{1}$ & 13,1656 & 1 & 13.1656 & 10.60 & $* *$ \\
$\beta_{2}$ & 1749,89 & 1 & 1749.89 & 1408.58 & $* * *$ \\
$\beta_{3}$ & 661,464 & 1 & 661.464 & 532.45 & $* * *$ \\
$\beta_{11}$ & 0,233409 & 1 & 0.233409 & 0.19 & $N S$ \\
$\beta_{12}$ & 1,125 & 1 & 1.125 & 0.91 & $N S$ \\
$\beta_{13}$ & 0,125 & 1 & 0.125 & 0.10 & $N S$ \\
$\beta_{22}$ & 1303,55 & 1 & 1303.55 & 1049.29 & $* * *$ \\
$\beta_{23}$ & 6,125 & 1 & 6.125 & 4.93 & $N S$ \\
$\beta_{33}$ & 105,638 & 1 & 105.638 & 85.03 & $* * *$ \\
Residue & 7.45388 & 6 & 1.24231 & - & - \\
\hline
\end{tabular}

$* * *$ : Prob. $\leq 0.01, * *$ : Prob. $\leq 0.025$, NS: No significant.

A geometrical representation for the decolourization efficiency of acid red 14 effluents by coagulation processes with SIWW, which is dependent on the coagulant dosage and initial $\mathrm{pH}$ of acid dye solutions, for constant values of the dye concentration $\left(X_{3}=0\right)$, is indicated on Fig. 2. As can be seen from Fig. 2, when the coagulant dosage $\left(X_{2}=-\alpha\right.$ to 0$)$ increase and the initial $\mathrm{pH}$ of acid dye solutions increase together or remaining unchanged, then the decolourization efficiency of acid red 14 effluents increase up to $97 \%$.

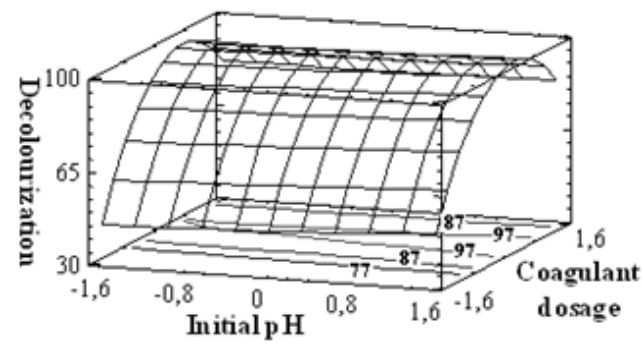

Figure 2. Response surface plot showing the effect of coagulant dosage and initial pH of dye solution on acid dye solution decolourization at fixed dye concentration $(150 \mathrm{mg} / \mathrm{mL})$

\subsection{COD Reduction of Acid Red 14 Effluents}

For COD reduction of acid red 14 effluents by coagulation processes with SIWW, the ANOVA for this response is listed in Table 6.

From this ANOVA, the Model F-value of 30.01 implied that the model was significant as well. In this case, the linear terms $\left(\mathrm{X}_{1}, \mathrm{X}_{2}\right.$ and $\left.\mathrm{X}_{3}\right)$ and the interaction terms $\left(\mathrm{X}_{1}^{2}, \mathrm{X}_{2}^{2}, \mathrm{X}_{3}^{2}\right.$ and $\mathrm{X}_{1} \mathrm{X}_{2}$ ) were significant model terms whereas the interaction terms $\left(\mathrm{X}_{1} \mathrm{X}_{3}\right.$ and $\left.\mathrm{X}_{2} \mathrm{X}_{3}\right)$ were insignificant to the response.

Fig. 3 shows the three-dimensional response surfaces which was constructed to show the effects of the coagulant dosage and the initial $\mathrm{pH}$ of acid dye solutions on the COD reduction of acid red 14 effluents by coagulation processes with SIWW. The dye concentration was fixed at zero level. From this geometrical representation, when the coagulant dosage $\left(\mathrm{X}_{2}=\right.$ $-\alpha$ to 0 ) increase and the initial $\mathrm{pH}$ of acid dye solutions 
remaining unchanged, then the COD reduction of acid red 14 effluents increase up to $93 \%$.

Table 6. Analysis of variance for COD reduction of acid dye solution

\begin{tabular}{llllll}
\hline $\begin{array}{l}\text { Source of } \\
\text { variation }\end{array}$ & $\begin{array}{l}\text { Sum of } \\
\text { Squares }\end{array}$ & $\begin{array}{l}\text { Degree of } \\
\text { freedom }\end{array}$ & $\begin{array}{l}\text { Mean } \\
\text { square }\end{array}$ & $\boldsymbol{F}_{\text {exp }}$ & $\begin{array}{l}\text { Significance } \\
\text { test }\end{array}$ \\
\hline Regression & 11081.23 & 9 & 1231.25 & 30.01 & $* * *$ \\
$\beta_{1}$ & 1847.96 & 1 & 1847.96 & 45.04 & $* * *$ \\
$\beta_{2}$ & 5655.20 & 1 & 5655.20 & 137.84 & $* * *$ \\
$\beta_{3}$ & 396.056 & 1 & 396.056 & 9.65 & $* *$ \\
$\beta_{11}$ & 528.291 & 1 & 528.291 & 12.88 & $* *$ \\
$\beta_{12}$ & 312.5 & 1 & 312.5 & 7.62 & $*$ \\
$\beta_{13}$ & 18.0 & 1 & 18.0 & 0.44 & $N S$ \\
$\beta_{22}$ & 2435.36 & 1 & 2435.36 & 59.36 & $* * *$ \\
$\beta_{23}$ & 18.0 & 1 & 18.0 & 0.44 & $N S$ \\
$\beta_{33}$ & 1489.05 & 1 & 1489.05 & 36.29 & $* * *$ \\
Residue & 246.172 & 6 & 41.0287 & - & - \\
\hline
\end{tabular}

***: Prob. $\leq 0.01, * *$ : Prob. $\leq 0.025, *$ : Prob. $\leq 0.05$, NS: No significant.

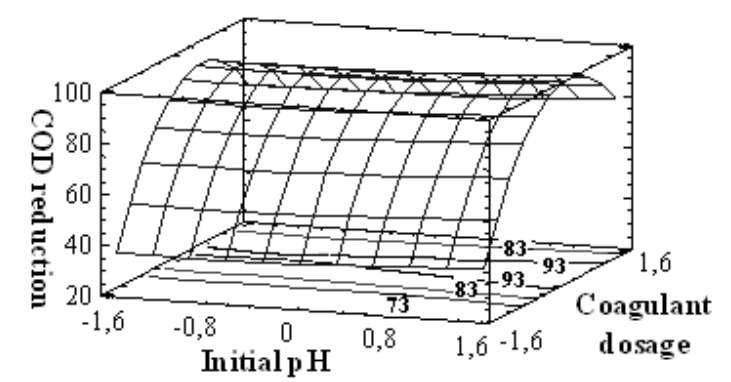

Figure 3. Response surface plot showing the effect of coagulant dosage and initial $\mathrm{pH}$ of dye solution on acid dye solution COD reduction at fixed dye concentration $(150 \mathrm{mg} / \mathrm{mL})$

\subsection{Process Optimization}

The main objective of this research is to determine the experimental conditions required to remove dye colour and COD. Then, using above mentioned methodology for experimental design, the ranges of the parameters required to obtain optimum conditions were determined. In this optimization study, decolourization efficiency and COD reduction of the acid red 14 effluents were chosen as the objective function. Furthermore, optimum conditions are often calculated in the presence of some constraints which ensure them to be more realistic. If the model used in the optimization study is an empirical one, high and low levels of the process parameters in the experimental design are considered, inevitably, as explicit constraints, in order to avoid extrapolation. Thus, the optimization problem is defined both responses as [29];

- Maximize;

$$
\hat{\mathrm{Y}}_{\mathrm{DEC}} / \hat{\mathrm{Y}}_{\mathrm{COD}}
$$

- Constraints on the parameters X;

$$
-\alpha_{i}<X_{\mathrm{i}}<+\alpha_{i} \quad \mathrm{i}=1,2,3
$$

The investigation of equations 4 and 5 showed that, if $\mathrm{X} 1=$ $1.25, \mathrm{X} 2=0$ and $\mathrm{X} 3=0$; the value predict of decolourization efficiency and COD reduction are $96.67 \%$ and $92.89 \%$, respectively. The experimental checking in this point, i.e. under the conditions such as: initial $\mathrm{pH}$ of acid dye solution $=$ 5.25 , coagulant dosage $=1 \mathrm{~mL}$ and dye concentration $=150$ $\mathrm{mg} / \mathrm{L}$ with $\mathrm{Y}_{\mathrm{DEC}}=98 \%$ and $\mathrm{Y}_{\mathrm{COD}}=94 \%$, confirms this results.

\section{Conclusion}

The present study clearly demonstrated the applicability of SIWW is very effective coagulant for dye removal. This study showed that response surface methodology was one of the suitable methods to optimize the best operating conditions to maximize the dye removal. Graphical response surface was used to locate the optimum point. A central composite rotatable design was successfully employed for experimental design and analysis of results.

\section{References}

[1] A. Adak, M. Bandyopadhyay, A. Pal, Fixed bed column study for the removal of crystal violet (C. I. Basic Violet 3) dye from aquatic environment by surfactant-modified alumina, Dyes Pigments 69 (2006) 245-251.

[2] V.K. Garg, M. Amita, R. Kumar, R. Gupta, Basic dye (methylene blue) removal from simulated wastewater by adsorption using Indian Rosewood sawdust: a timber industry waste, Dyes Pigments 63 (2004) 243-250.

[3] C.I. Pearce, J.R. Lloyd, J.T. Guthrie, The removal of colour from textile wastewater using whole bacterial cells, Dyes Pigments 58 (2003) 179-196.

[4] C.C.I. Guarantini, M.V.B. Zanoni, Corantes Têxteis, Química Nova 23 (2000) 71-78.

[5] E. Forgacs, T. Cseháti, G. Oros, Removal of synthetic dyes from wastewaters, Environ. Int. 30 (2004) 953-971.

[6] A. Pala, E. Tokat, Color removal from cotton textile industry wastewater in an activated sludge system with various additives, Water Res. 36 (2002) 2920-2925.

[7] H. Chun, W. Yizhong, Decolorization and biodegradability of photocatalytic treated azo dyes and wool textile wastewater, Chemosphere 39 (1999) 2107-2115.

[8] T. Robinson, B. Chandran, P. Nigam, Removal of dyes from a synthetic textile dye effluent by biosorption on apple pomace and wheat straw, Water Res. 36 (2002) 2824-2830.

[9] A. Bhatnagar, A.K. Jain, M.K. Mukul, Removal of congo red dye from water using carbon slurry waste, Environ. Chem. Lett. 2 (2005) 199-202.

[10] R. Gong, Y. Ding, M. Li, C. Yang, H. Liu, Y. Sun, Utilization of powdered peanut hull as biosorbent for removal of anionic dyes from aqueous solution, Dyes Pigments 64 (2005) 187-192.

[11] P. Peralta-Zamora, A. Kunz, S.G. De-Moraes, R. Pelegrini, P.D. Moleiro, J. Reyes, Degradation of reactive dyes: A comparative study of ozonation, enzymatic and photochemical processes, Chemosphere 38 (1999) 835-852.

[12] D. Georgiou, P. Melidis, A. Aivasidis, K. Gimouho-Poulos, Degradation of azo-reactive dyes by ultraviolet radiation in the presence of hydrogen peroxide, Dyes Pigments 52 (2002) 69-78. 
[13] L.S. Tsui, W.R. Roy, M.A. Cole, Removal of dissolved textile dyes from wastewater by a compost sorbent, Coloration Technol. 119 (2003) 14-18.

[14] G. Annadurai, R.S. Juang, D.J. Lee, Factorial design analysis for adsorption of dye on activated carbon beads incorporated with calcium alginate, Adv. Environ. Res. 6 (2002) 191-198.

[15] V. Gokmen, A. Serpen, Equilibrium and kinetic studies on the adsorption of dark colored compounds from apple juice using adsorbent resin, J. Food Eng. 53 (2002) 221-227.

[16] K.R. Ramakrishna, T. Viraraghavan, Use of slag for dye removal, Waste Manage. 17 (8) (1997) 483-488.

[17] H.L. Liu, Y.R. Chiou, Optimal decolorization efficiency of Reactive Red 239 by $\mathrm{UV} / \mathrm{TiO}_{2}$ photocatalytic process coupled with response surface methodology, Chem. Eng. J. 112 (2005) 173-179.

[18] J. Wu, M.A. Eiteman, S.E. Law, Evaluation of membrane filtration and ozonation processes for treatment of reactive dye wastewater, J. Environ. Eng. 124 (1998) 272-277.

[19] D. Mohan, K.P. Singh, G. Singh, K. Kumar, Removal of dyes from wastewater using flyash, a low-cost adsorbent, Ind. Eng. Chem. Res. 41 (15) (2002) 3688-3895.

[20] I. Arslan, I.A. Balcioglu, D.W. Bahnemann, Advanced chemical oxidation of reactive dyes in simulated dyehouse effluents by ferrioxalate-Fenton/UVA and $\mathrm{TiO}_{2} / \mathrm{UV}-\mathrm{A}$ processes, Dyes Pigments 47 (2000) 207-218.

[21] V. Golob, A. Vinder, M. Simonic, Efficiency of the coagulation/flocculation method for the treatment of dye bath effluents, Dyes Pigments 67 (2005) 93-7.
[22] M.A. Aboulhassan, S. Souabi, A. Yaacoubi, Pollution reduction and biodegradability index improvement of tannery effluents, Int. J. Environ. Sci. Technol. 5 (1) (2008) 11-16.

[23] M.A. Aboulhassan, S. Souabi, A. Yaacoubi, M. Baudu, Treatment of textile wastewater using a natural flocculant, Environ. Techno. 26 (2005) 705-711.

[24] R.H. Myers, D.C. Montgomery, Response surface methodology: process and product optimization using designed experiments, John Wiley \& Sons, New York, 1995.

[25] Abdelkader Anouzla, Salah Souabi, Mohamed Safi, Younes Abrouki, Hayat Loukili, Hicham Rhbal. Waste to Treat Waste of Landfill Leachates. International Journal of Environmental Protection and Policy (IJEPP) Volume 2, Issue 2, 2014, Pages 50-53.

[26] Abdelkader Anouzla, Younes Abrouki, Salah Souabi, Mohamed Safi, Hicham Rhbal. Chapitre 12 «Optimization and Modeling of Decolorization and COD Reduction of Reactive Dye Solutions by Coagulation Processes with SIWW's Coagulant » The Role of Colloidal Systems on Environmental Protection 2014 Pages 279-288.

[27] APHA, AWWA, WPCF, Standard methods for the examination of water and wastewater, DC, Washington, 1998.

[28] G.M. Clarke, R.E. Kempson, Introduction to the Design and Analysis of Experiments, Arnold, London, 1997.

[29] E. Şayan, Optimization and modeling of decolorization and COD reduction of reactive dye solutions by ultrasound-assisted adsorption, Chem. Eng. J. 119 (2006) 175-181. 